\title{
Peter Karmel: A Tribute
}

\section{Geoff Harcourt ${ }^{1}$}

In November 2008 Bob Wallace and I visited Peter Karmel at his Canberra home. We had our photo taken, by Joan Harcourt, holding a copy of Economic Activity (1967), that had been written by the three of us, and which had just been reissued

by Cambridge University Press. It was my first book and Peter's third. ${ }^{2}$ We had a very happy hour and a half. Sadly, it was the last time we were to see our much-admired and highly valued friend and colleague, who subsequently passed away at the age of 86 on 30 December 2008.

When I came to Adelaide in March 1958 to my first lecturing post, Peter was the still very young Professor of Economics at Adelaide (aged 28 when appointed in 1950). I had heard him as an undergraduate give the G. L. Wood Memorial Lecture, and he had interviewed me in early 1958 for the Adelaide post while I was doing a PhD at Cambridge. It was at Adelaide that I came to know him well before, to our great collective chagrin, he went to Flinders as its first Vice-Chancellor in 1962. When he called us into the tearoom to tell us the news, we all moaned about our lot at losing him. It was almost only as an afterthought that Frank Jarrett congratulated him on his new post!

Peter was a wonderful head. He was democratic and approachable; he also created the fiction that each one of us was his most trusted confidant so that when decisions were taken, they were almost always approved of because he had found out what the dogs were barking beforehand. He created an atmosphere of exciting intellectual teamwork, with all of us joining in, often in the tearoom, in discussions of economic and other issues, which fed into the creation of our and his papers. It was an extraordinarily happy and productive period with Peter, Eric Russell, Ron Hirst, Frank Jarrett, Russell Mathews, John Grant, Bob Wallace, Keith Hancock, Hugh Hudson, Donald Whitehead, Maureen Brunt, John Dillon, Alan Powell, Allan Barton - I could go on, but you get the picture: a youthful and outstanding department.

Rightly, Peter is greatly admired for his splendid work as a university administrator, for his contributions to higher and secondary education, for his roles in all manner of major government reports, and for his input into the arts, not least being the remarkable collection of paintings and sculptures that he and Lena built up at their Canberra home. But he was also an absolutely first-class

\footnotetext{
1 Jesus College, Cambridge. Correspondence: j.starnes@jesus.cam.ac.uk

${ }^{2}$ His two previous books were The Structure of the Australian Economy (1963), co-authored with Maureen Brunt, and Applied Statistics for Economists (1957). As Allan Barton noted in his splendid Eulogy at Peter's funeral, Applied Statistics for Economics, was 'an instant success', and adopted as 'the' textbook for many years.
} 
economist with a capacity for work at an intensity for the whole day which most of us could not sustain for even two hours, if at all. His PhD at Cambridge, predicting population growth by looking at male fertility, was highly original and extremely technical; it resulted in a number of papers in brownie-point journals. I read his dissertation when I was in Cambridge in the 1950s, but I would be kidding if I said I could do anything other than admire it. So I shall write about his economics papers which I think I understand more.

Peter and Bob Wallace published a seminal article, entitled 'Credit creation in a multi-bank system', in the first ever issue of Australian Economic Papers in September 1962. It concerned the fallacy of analysing the banking system by using a representative bank as opposed to a population of interacting banks. Their work - or rather, the issue - was not taken up again until a couple of years ago, by the authors of a paper in the Cambridge Journal of Economics, who had to be referred to Bob and Peter's paper. Bob and Peter were decades ahead of the pack in exposing the fallacy of using single representative agent models in macroeconomic analysis. Through a number of carefully worked out cases, going from the simplest to complex ones, they illustrated how misleading the traditional method of examining the effects of changes in the conditions under which banks worked could be. They analysed whether convergence on a new equilibrium position or fluctuations around it would result, using both analytical and simulation approaches to get a 'feel' on the problems. Their exposition exhibits deep economic intuition allied with technical analysis which gives the reader confidence that the authors are completely on top of what they are doing.

Peter collaborated with Adelaide mathematicians B. C. Rennie and George Sved when he took issue in the Economic Record (Karmel 1959a) with John Pitchford and Alf Hagger, who had published a note in the Economic Journal in 1958 on the possibility of multiple rates of return on investment projects when some of the expected cash flows were negative. Peter showed 'that, if a project is terminable at any stage during its [expected] lifetime and provided that the scrap value is always non-negative, the marginal efficiency of the truncated project expected to have the highest marginal efficiency will be a unique value' (p.430). Negative cash flows were shown to produce multiple values 'only in very special circumstances'. The paper is marked by crystal-clear exposition, helpful diagrams and supporting algebraic proofs, including an addendum criticising Sam Soper's further note on the same issue in the March 1959 Economic Journal. In Adelaide we always thought that Roy Harrod, then editor of the Economic Journal, erred in rejecting Peter's definitive critique of Pitchford, Hagger, and Soper.

Perhaps above all, Peter was a major player in the formulation of wages/incomes policy for Australia, even if, as I believe, Eric Russell and Wilfred Salter made the deepest contributions here. In his most substantial article on 
these issues - his Presidential Address to Section G, A.N.Z.A.A.S. in 1959 he acknowledges 'great indebtedness' to Eric's Statement of Evidence to the Arbitration Commission in the Basic Wage Case. There Eric argued that average real wages should be tied to 'effective productivity' — national productivity adjusted for the terms of trade. ${ }^{3}$ Peter's address, published as 'Some reflections on inflation, productivity and growth' (Karmel 1959b), contained a comprehensive analysis of the interrelationships between the three. Peter was especially keen to get away from the then Australian practice of regarding growth of the economy as 'a residual objective'. He wanted it placed on the same footing as full employment (without much inflation), and an equitable distribution of income, including systematic provision of public infrastructure. The Address is a model of clarity and sustained, joined-up arguments, with the formal analysis presented in footnotes. Peter belonged to the generation that was brought up on the 'Trinity' of The General Theory, Value and Capital and The Foundations and he followed Hicks's example of persuasive prose in the text ${ }^{4}$ and the mathematics in footnotes or appendices. Peter's wide reading is evident in his discussion of, for example, growth, where the contributions of Frank Ramsey and Roy Harrod clearly underlie his analysis. ${ }^{5}$

Peter took a pragmatic view on how 'close' to full employment we should aim to be. He was sceptical of Paish's view that some slack was necessary in order to allow resource allocation to do its thing through the relative price mechanism, because Peter had a real sense of the need for buoyant 'animal spirits' to sustain private investment at levels which would lead to the productivity gains from the embodiment of new ideas in the capital stock through investment.

Peter was a wonderful teacher: clear, enthusiastic and able to put over large amounts of material which, nevertheless, all but the weakest students could absorb and understand. I took over his first-year course in 'Outlay', when he was appointed to Flinders and he lent me his very full lecture notes. They were the inspiration for our co-authored book with Bob Wallace, Economic Activity. When I was in Cambridge in 1963-66, I taught the first-year macro course from its proof sheets. One of my listeners was Mervyn King, now Governor of the Bank of England. I am delighted to report that three times in public (to my knowledge) Mervyn has paid tribute to its contents and presentation, saying in effect that it formed the basis of his understanding of macro economics.

Peter was a great economist and public citizen, a humane liberal thinker who always wanted to apply economics to improving the lot of his fellow Australians,

\footnotetext{
3 The relevant pages are 353-4 and 366 (n.19).

4 Eric used to say that Hicks wrote so well he made the confusions clear.

${ }^{5}$ On the specific issue of wages/incomes policy, he had not yet come to Eric's (and Salter's) view that money wages should be adjusted for both overall productivity and prices, though Peter does make a reference to the classic 1957 Russell-Meade paper in the Economic Record on how the Australian economy works, which was the foundation of Eric's views.
} 
especially those who were not as gifted as him, nor as fortunate in their opportunities. He had an earthy sense of humour, innumerable friends and no real enemies (though Bob Menzies treated him very badly over the Vernon Report).

Most of all, Peter was a tremendous, devoted family man. He and Lena had six children and 16 grandchildren. The family was the centre of his being, and he and Lena formed the most wonderful team. Peter described Lena as 'the rock upon which the family has been built'. The Karmels also gave superb Faculty parties, and were kind, supportive yet really down-to-earth friends, always calling things as they were. It has been an enormous privilege to have known them.

\section{References}

Karmel, Peter 1959a, 'The Marginal Efficiency of Capital' , Economic Record 35(2): 429-34.

Karmel, Peter 1959b 'Some Reflections on Productivity, Inflation and Growth', Economic Record 35(2): 349-63.

Meade, J. E. and Russell, E. A. 1957, 'Wage rates, the Cost of Living and the Balance of Payments', Economic Record 33(1): 23-8.

Pitchford, J. D. and Hagger, A. J. 1958, 'A Note on the Marginal Efficiency of Capital', The Economic Journal 68(271): 597-600.

Soper, C. S. 1959, 'The Marginal Efficiency of Capital: A Further Note', The Economic Journal 69(273): 174-7.

Wallace, Bob and Karmel, Peter 1962, 'Credit creation in a multi-bank system', Australian Economic Papers 1. 